\title{
Rehydration conditions for isolation of high quality RNA from the lichen Lobaria pulmonaria
}

\author{
Jennifer A Doering ${ }^{1}$, Vivian PW Miao ${ }^{2}$ and Michele D Piercey-Normore ${ }^{1 *}$
}

\begin{abstract}
Background: The poikilohydric nature of lichens enables them to survive repeated episodes of desiccation by utilizing water when it becomes available. During rehydration, RNA-degrading endonucleases may be released, reducing RNA quantity and quality. Re-generation of a steady-state condition where RNA quantity and quality no longer fluctuate establishes a framework for development of new hypotheses for future investigations. Using Lobaria pulmonaria as a model species, the objective of this study was to compare the effect of different rehydration conditions on the quantity and quality of RNA from the rehydrated thallus.
\end{abstract}

Findings: Spectrophotometric measurements of total RNA and CDNA were performed for samples prepared from dry lichen or lichen after rehydration $(0.5 \mathrm{~h}, 1 \mathrm{~h}, 2 \mathrm{~h}, 4 \mathrm{~h}$ or $24 \mathrm{~h})$, with limited light and dark conditions, and at three temperatures $\left(15^{\circ} \mathrm{C}, 20^{\circ} \mathrm{C}\right.$ or $\left.32^{\circ} \mathrm{C}\right)$ for some of these conditions. The results showed that rehydration of the thallus for $4 \mathrm{~h}$ at $20^{\circ} \mathrm{C}$ in light yielded the highest concentration and quality of RNA. A higher RNA concentration was obtained in light than in dark conditions, but the RNA quality was unaffected.

Conclusions: This study suggests that allowance of $4 \mathrm{~h}$ for thallus rehydration should be adequate to ensure complete recovery of transcription. After $4 \mathrm{~h}$ at $20^{\circ} \mathrm{C}$ further studies can be carried out on the RNA in this model species.

Keywords: CDNA, Lichen, Lobaria pulmonaria, RNA quality, RNA quantity, RT-PCR, Total RNA

\section{Background}

Water scarcity limits survival for most vascular plants because they cannot tolerate extensive dehydration. Poikilohydric organisms such as lichens and mosses have no mechanism to prevent dehydration, but can recover from low cell water content without physiological damage. Recovery of metabolic activity, such as transcription, upon rehydration has been studied in the vascular resurrection plant and moss [1], and is of interest in lichens.

Lichens are symbiotic associations between a lichenforming fungus (mycobiont) and a green alga and/or a cyanobacterium [2] (photobionts). Lobaria pulmonaria is a foliose (leaf-like) lichen found in old growth forests [3]. The mycobiont (also designated L. pulmonaria) in this lichen is accompanied by both a green algal, Dictyochloropsis reticulata [4] and a cyanobacterial, Nostoc sp. [5] symbiont. L. pulmonaria has been considered as a model species by

\footnotetext{
* Correspondence: Michele.Piercey-Normore@umanitoba.ca

'Department of Biological Sciences, University of Manitoba, 50 Sifton Road,

Winnipeg, MB R3T 2 N2, Canada

Full list of author information is available at the end of the article
}

some researchers $[4,6]$ and has been extensively studied from the perspective of herbivory [7], population genetics and dispersal [4], physiology [8], conservation biology [9], and sexual reproduction $[10,11]$.

Most lichen and bryophyte thalli will dehydrate and rehydrate as the humidity in the surrounding atmosphere changes. Poikilohydric responses coincide with changes in the cell structure, biochemistry and physiology, e.g. photosynthesis [12]. One of the early activities of metabolism upon restoration of cell function after desiccation is thought to be transcript formation [1], in part because synthesis of antioxidant proteins protects cells from the rapid intracellular release of reactive oxygen species after rehydration [12]. However, RNA-degrading endonucleases released during rehydration [13], may reduce RNA quantity and quality [14]. After the effects of rehydration reach a steady-state condition representative of the natural lichen, further experimentation provides the opportunity to investigate a variety of questions such as the ecological plasticity of the lichen by monitoring phenotypic, physiological or transcriptional metrics in response to different 
rehydration conditions. Re-generation of a steady-state condition is very useful in setting up a framework for development of new hypotheses for future investigations. While it has been shown that RNA can be retrieved from rehydrated Cladonia rangiferina thalli [15], that RNA-seq analyses have been performed on natural lichens $[16,17]$ and a cDNA library has been produced from rehydrated samples of the moss, Tortula ruralis [1], the establishment of a steady-state condition after thallus rehydration has not been examined.

The objective of this study was to compare the effect of different rehydration conditions on the quantity and quality of RNA from the thallus of L. pulmonaria, using total RNA and cDNA by reverse transcription PCR and the $\mathrm{A}_{260 / 280}$ absorbance ratio.

\section{Methods}

Naturally desiccated thalli of Lobaria pulmonaria were collected in British Columbia, Canada between November and December 2011, and kept dry and in the dark at $-20^{\circ} \mathrm{C}$ until used for experiments. Two specimens (VM5172 and VM5174) were collected from very large branches (more than15 feet long) of maple (Acer macrophylum) thought to have broken from the canopy during autumn storms, no more than 2-3 months earlier along Yellow Point Lodge trail, near Ladysmith, southeastern Vancouver Island. Another specimen (VM5190) was removed from the bole of a standing tree at Cultus Lake, $\sim 100 \mathrm{~km}$ east of the city of Vancouver. Small pieces were excised from each lichen specimen, trimmed to $70-100 \mathrm{mg}$ dry weight (DW), and then either kept dry (control), or rehydrated in $600 \mu \mathrm{L}$ of sterile distilled water under various temperature and light regimes for up to $24 \mathrm{~h}$ (Table 1). A Low Temperature Incubator
(Fisher Scientific, Ottawa, Canada), a Gravity Convection Incubator (Precision Scientific, Chennai, India) and an Innova40 Incubator (New Brunswick Scientific, Enfield, USA) held at $15^{\circ} \mathrm{C}, 20^{\circ} \mathrm{C}$, or $32^{\circ} \mathrm{C}$, respectively, were used. Light was supplied by Grow Lamps (Vita Lite, Duro test, $20 \mathrm{~W}$ ) at $60 \mu \mathrm{mol}$ photons $\mathrm{m}^{-2} \mathrm{~s}^{-1}$ in the $20^{\circ} \mathrm{C}$ and $32^{\circ} \mathrm{C}$ chambers and at $6 \mu \mathrm{mol}$ photons $\mathrm{m}^{-2} \mathrm{~s}^{-1}$ in the $15^{\circ} \mathrm{C}$ chamber.

RNA was isolated from samples ground in a mortar and pestle with Trizol (Life Technologies Inc., Burlington, Canada), and initial yield and quality were estimated spectrophotometrically using a NanoDrop 2000/2000c (ThermoScientific, Ottawa, Canada). Removal of contaminating DNA was achieved with a DNase kit (Life Technologies Inc., Burlington, Ontario) and the absence of contaminating DNA was confirmed by gel electrophoresis in $1 \%$ agarose and by performing PCR for mtr SSU (below). RNA samples were re-measured on the NanoDrop 2000/2000 c and re-checked on a 1\% agarose gel. A cDNA synthesis kit (ThermoScientific, Ottawa, Canada) was then used to synthesize cDNA from the cleaned RNA using oligo $\mathrm{dT}$ and random primers.

PCR reactions from cDNA were conducted in $20 \mu \mathrm{l}$ with 0.4-2 $\mu$ g template, $1 \times$ PCR Buffer $(200 \mathrm{mM}$ Tris$\mathrm{HCl}, \mathrm{pH} 8.4 ; 500 \mathrm{mM} \mathrm{KCl}), 0.1 \mu \mathrm{M}$ each dNTP, $2.5 \mathrm{mM} \mathrm{MgCl} 2,0.4 \mathrm{mM}$ each primer and $1 \mathrm{U}$ Pfu DNA polymerase, and were performed in a Biometra Tgradient thermal cycler (Applied Biosystems, Foster City, USA). The taxon-specific PCR primers used to detect sequences representing the fungal (mtr SSU, mitochondrial small subunit rRNA), algal ( $L p u \_27$, a simple sequence repeat) and cyanobacterial (nifH, nitrogenase) symbionts, were mtr SSU1/ mtr SSU2R [18], Lpu_27 F and $R$ [19] and NiFH-F/NiFH-R [20], respectively. A modified touchdown program [21] was used for detecting

Table 1 Experimental design showing 13 rehydration, light, and temperature conditions for three specimens of Lobaria pulmonaria

\begin{tabular}{|c|c|c|c|c|c|c|c|}
\hline Treatment & Rehydration with water & Temp $\left({ }^{\circ} \mathrm{C}\right)$ & Light & Rehydration time (hours) & $\begin{array}{l}\text { No. replicates } \\
\text { for VM5172 }\end{array}$ & $\begin{array}{l}\text { No. replicates } \\
\text { for VM5174 }\end{array}$ & $\begin{array}{c}\text { No. replicates } \\
\text { for VM5190 }\end{array}$ \\
\hline 1 & no & 20 & yes & 0 & 3 & 3 & 3 \\
\hline 2 & yes & 20 & yes & 0.5 & 3 & 3 & 3 \\
\hline 3 & yes & 20 & yes & 1 & 3 & 3 & 3 \\
\hline 4 & yes & 20 & yes & 2 & 3 & 3 & 3 \\
\hline 5 & yes & 20 & yes & 4 & 3 & 3 & 3 \\
\hline 6 & yes & 20 & yes & 24 & 3 & 3 & 3 \\
\hline 7 & yes & 20 & no & 1 & 3 & 3 & 3 \\
\hline 8 & yes & 20 & no & 4 & 3 & 3 & 3 \\
\hline 9 & yes & 32 & yes & 1 & 3 & 3 & 3 \\
\hline 10 & yes & 32 & yes & 4 & 3 & 3 & 3 \\
\hline 11 & yes & 15 & yes & 1 & 3 & 3 & 3 \\
\hline 12 & yes & 15 & yes & 4 & 3 & 3 & 3 \\
\hline 13 & yes & 15 & yes & 24 & 3 & 3 & 3 \\
\hline
\end{tabular}


$L p u \_27$ in representative preparations: denaturing at $94^{\circ} \mathrm{C}$ $3 \mathrm{~min}$, then 29 cycles of $94^{\circ} \mathrm{C} 30 \mathrm{~s}, 20 \mathrm{~s}$ annealing $\left(56^{\circ} \mathrm{C}\right.$ first 2 cycles, then $54^{\circ} \mathrm{C}$ for 27 cycles) and extension at $72^{\circ} \mathrm{C}$ $30 \mathrm{~s}$, then a final extension at $60^{\circ} \mathrm{C} 10 \mathrm{~min}$. The PCR program for nifH was: $94^{\circ} \mathrm{C} 5 \mathrm{~min}$, then 35 cycles of $94^{\circ} \mathrm{C}$ $1 \mathrm{~min}, 48^{\circ} \mathrm{C} 1 \mathrm{~min}, 72^{\circ} \mathrm{C} 1 \mathrm{~min} 15 \mathrm{~s}$, and finally $72^{\circ} \mathrm{C}$ $7 \mathrm{~min}$. For the mtr SSU-based PCR saturation curve experiment, $20 \mu \mathrm{l}$ aliquots from master mixes with or without cDNA template were delivered into PCR tubes and run in a PCR machine executing the following program: 25 cycles of $94^{\circ} \mathrm{C} 1 \mathrm{~min}, 54^{\circ} \mathrm{C} 30 \mathrm{~s}$, and $72^{\circ} \mathrm{C} 1 \mathrm{~min}$. A pair of tubes (one with template and the other a negative control) was removed after every 2 cycles beginning with cycle 8 , resulting in 9 pairs representing different numbers of cycles from 8 to 24 cycles. All other mtr SSU PCR experiments using cDNA employed only 17 cycles of amplification. Lichen DNA samples (extracted from source thalli following published methods [22]) were used as controls for some PCR, and these reactions were also conducted in $20 \mu \mathrm{l}$ mixtures, but consisted of $0.5-1 \mathrm{ng}$ template, $0.2 \mathrm{mM}$ each dNTP, $2 \mathrm{mM} \mathrm{MgCl} 2$, and $1 \mathrm{U}$ of Taq in $1 \times$ buffer (Life Technologies Inc., Burlington, ON) and either $0.2 \mu \mathrm{M}$ each primer (for $L p u \_27$ ) or $0.5 \mu \mathrm{M}$ each primer (for nifH). These experiments were run on a T100 thermal cycler (BioRad), using the same respective programs (above). All amplified products were electrophoresed on a $1 \%$ agarose gel and compared with a $1 \mathrm{~Kb}$ Plus DNA Ladder (Life Technologies Inc. Burlington, ON) for size estimation.

Statistical analyses were performed in the software program $\mathrm{R}$ [23]. Because the data were non-normally distributed (indicated by Anderson-Darling test of normality and Levene's test of equal variances), the Kruskal-Wallis test (non-parametric) was used to determine significant differences between temperatures, light, and rehydration times, and the Mann-Whitney test (non-parametric) was used to determine pairwise significant differences shown in the graphs.

\section{Findings}

Total RNA isolated from lichen thalli typically appeared as a smear (mRNA) with a sharp low molecular weight band (tRNA), and two bands representing $18 \mathrm{~S}$ and $26 \mathrm{~S}$ ribosomal RNAs (Figure 1). The yield of RNA was essentially the same from each of the three source specimens when all samples from each specimen $(n=39)$ were averaged together, viz. $2.9 \pm 1.6 \mu \mathrm{g} / \mathrm{gDW}, 3.0 \pm 2.0 \mu \mathrm{g} / \mathrm{gDW}$ and $3.0 \pm 1.8 \mu \mathrm{g} / \mathrm{gDW}$, respectively (Figure 1 ). The corresponding average RNA quality $\left(\mathrm{A}_{260 / 280}\right)$ for VM5172 was $1.7 \pm 0.2$, for VM5190 was $1.7 \pm 0.1$; for VM5174 was $1.7 \pm 0.1$. However, the variance around the average quality differed among the three source specimens. Kruskal-Wallis (non-parametric ANOVA, p < 0.001) and Mann-Whitney (non-parametric t-test, $\mathrm{p}<0.050$ for

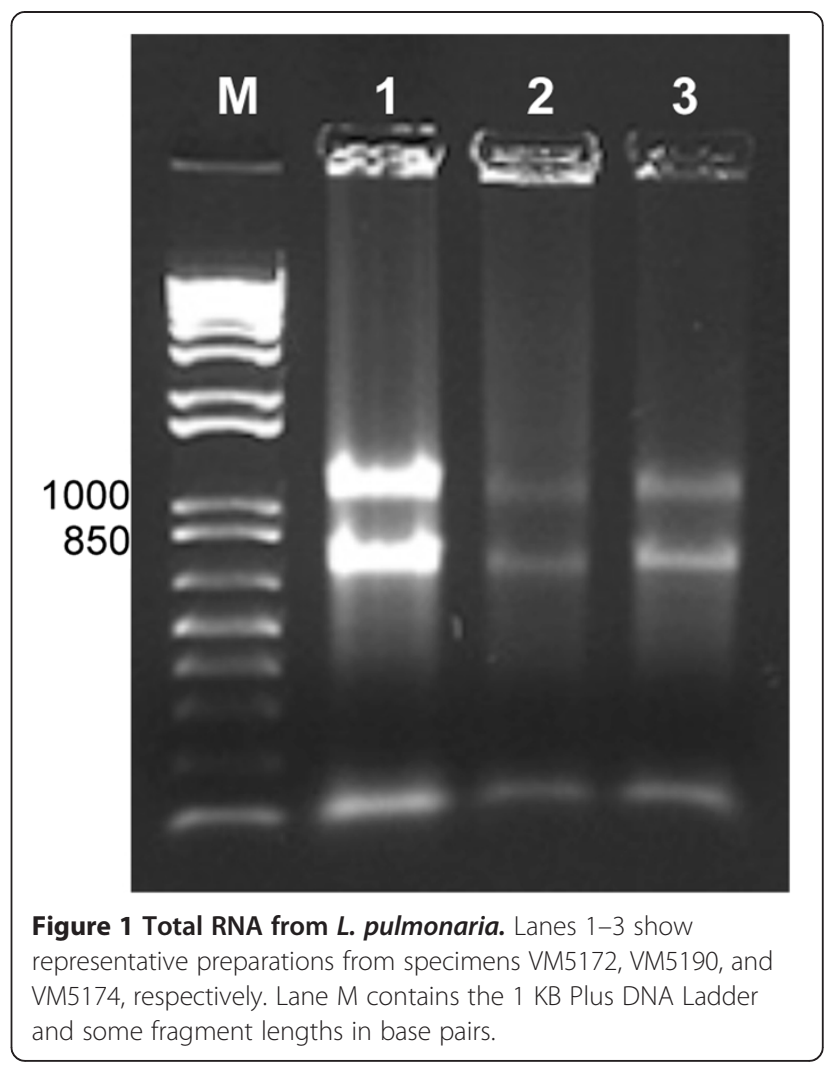

comparison between VM5172 and VM5190; $\mathrm{p}<0.001$ for comparison between VM5174 and VM5190; $p>0.050$ for the comparison between VM5172 and VM5174) tests showed that RNA quality of VM5190 was significantly higher than that of VM5174 and VM5172, but that there was no difference between the latter.

Significantly more RNA was recovered from samples rehydrated at $20^{\circ} \mathrm{C}$ for $1 \mathrm{~h}, 4 \mathrm{~h}$, and $24 \mathrm{~h}$ than from those treated for $0.5 \mathrm{~h}$ and $2 \mathrm{~h}$ (Figure 2A), but there was overall no difference in RNA purity, as assessed by $\mathrm{A}_{260 / 280}$ ratio (Figure $2 \mathrm{~B}$ ). Incubation at $20^{\circ} \mathrm{C}$ was more productive than at either higher $\left(32^{\circ} \mathrm{C}\right)$ or lower $\left(15^{\circ} \mathrm{C}\right)$ temperatures (Figure $2 \mathrm{C}$ ) and after $4 \mathrm{~h}$ rehydration, gave higher quality RNA (Figure 2D). Rehydration of lichen thalli in the light resulted in a higher yield of RNA (Figure 2E) without affecting quality (Figure 2F).

Reverse transcription PCR (RT-PCR) was also used to assess the quality of total $L$. pulmonaria RNA. Tests for taxon-specific genetic markers, mtr SSU, Lpu_27, and nifH, on cDNA synthesized with both oligo dT and random primers indicated that the mycobiont as well as both photobionts of $L$. pulmonaria were all represented (data not shown). Using mtr SSU as the mycobiont reference gene, trials with increasing numbers of amplification cycles were conducted and saturation of the 


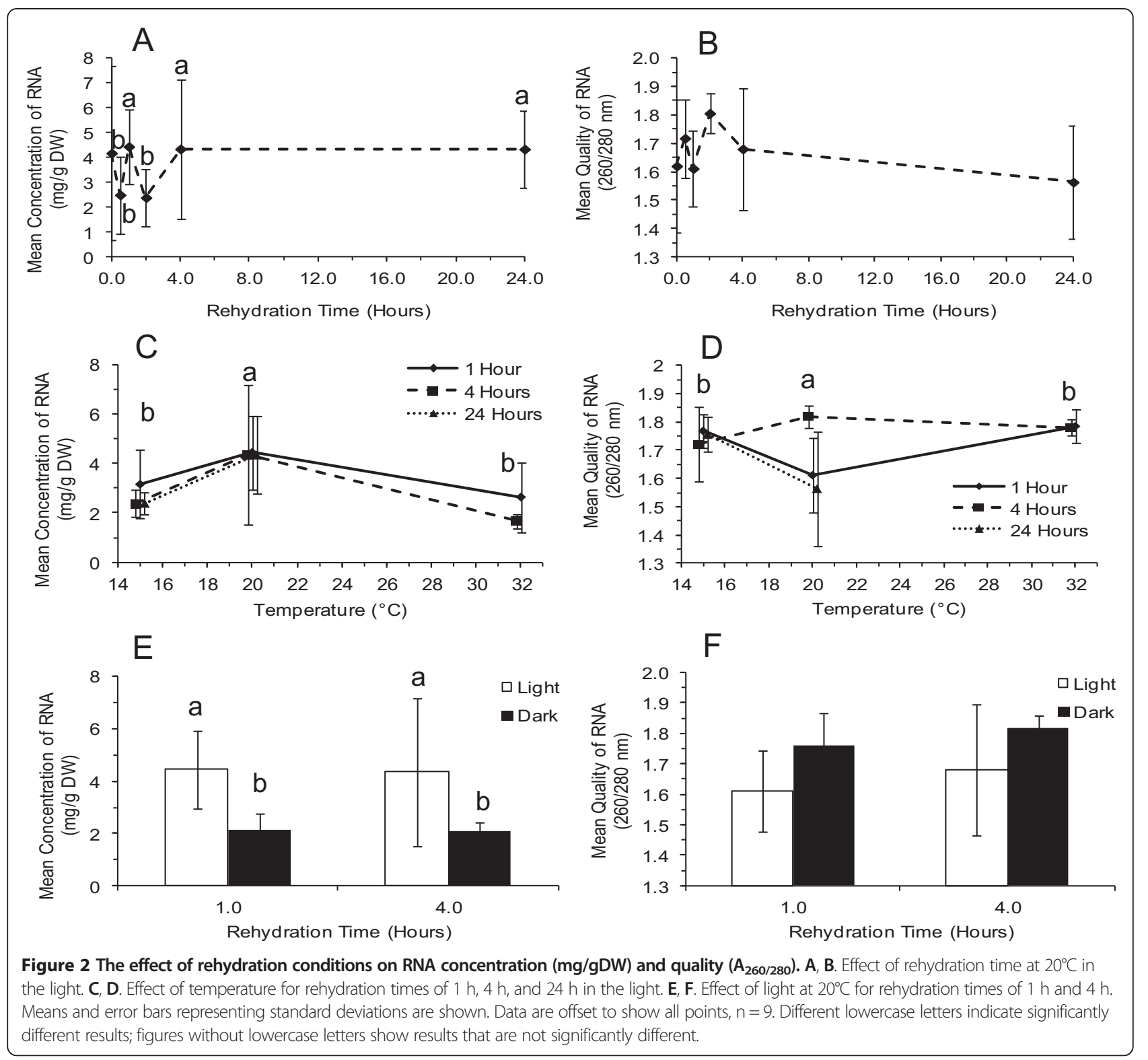

PCR curve was observed between 17 and 21 cycles (Figure 3). This allowed standardization of RT-PCR tests at 17 cycles for a sensitive measure of original RNA quality based on amplicon accumulation. As found earlier by direct spectroscopic assessment of total RNA, the best results from RT-PCR were associated with samples rehydrated for $1 \mathrm{~h}$ and $4 \mathrm{~h}$ durations (Figure $4 \mathrm{~A}$ ) and $20^{\circ} \mathrm{C}$ (Figure 4B); again, there was no significant influence of light during incubation (Figure 4C).

\section{Discussion}

The amount of RNA isolated, which was normalized for thallus dry weight, was smaller in this study than that in a study on Cladonia rangiferina [15], but whether this is of significance is unclear as the composition and morphology of the two lichens are very different. The very small amounts of starting material used here may be a factor, as the percentage loss during mortar grinding may be proportionately larger. Overall, the key result is that RNA of sufficient quantity and quality can be recovered to detect all symbionts, indicating that future studies will be possible even where biomass may be limited. The present work suggests that a wide variation in yield (standard deviation of $55 \%$ to $66 \%$ of the total RNA was calculated over all conditions) might be expected when using the Trizol method, and that it is accompanied by an inverse relationship between RNA quality and quantity 


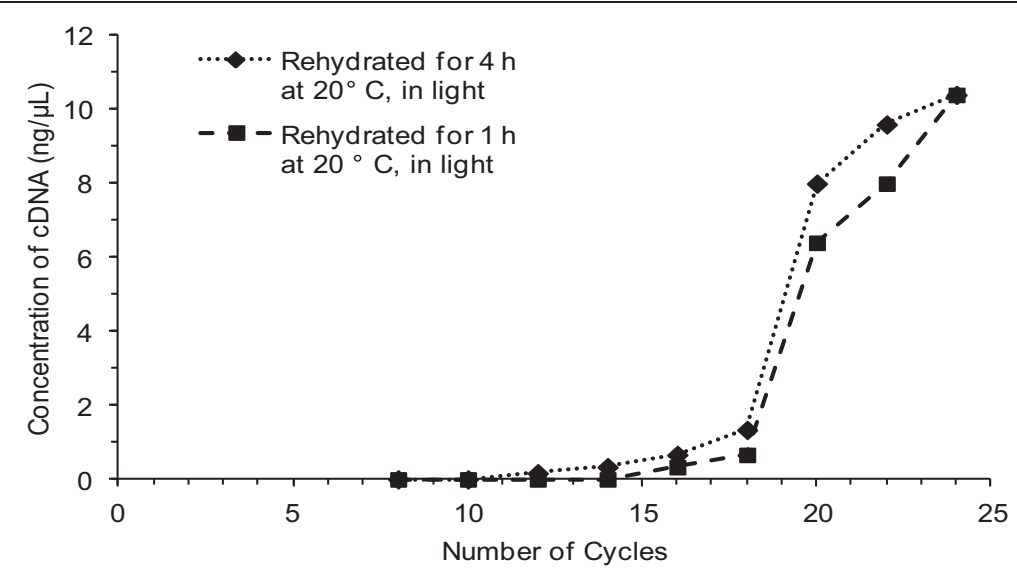

Figure 3 Saturation curves for rehydration conditions showing the concentration of CDNA and number of PCR cycles.

(Figure 2). This may be generally applicable, as the C. rangiferina study, which compared several methods, also reported standard deviations of $26 \%$ to $72 \%$ on the average yield (ca Table 1 [15]) and opposing trends between RNA quality and quantity.

The significant variation in RNA quality between thalli may, on first principles, be attributable to one or more variables such as different intrinsic metabolic rates of each thallus as a result of age, reproduction, stress, pollution, etc., or the dehydration and storage conditions that affect the revival capacity of the thallus [24] and therefore transcription. Interestingly, RNA quality was more similar between the two specimens from one locale (VM5172 and VM5174) than either compared to VM5190, from another locale. The environmental conditions in which each thallus was collected would provide a different acclimation process exposing each thallus to different levels of light and temperature regimes [6]. Therefore differences would be expected among thalli given the wide distribution and variation in habitat of the species [25]. Nostoc has been shown to have a significant increase in photosynthesis and gene activity upon rehydration [26]. The low variation in RNA concentration at $20^{\circ} \mathrm{C}$ (Figure 3 ) is reasonable since the optimal temperature for lichen growth and metabolism is thought to be $18^{\circ} \mathrm{C}$ to $20^{\circ} \mathrm{C}$ [2] and other studies also used rehydration temperatures between $18^{\circ} \mathrm{C}$ to $20^{\circ} \mathrm{C}$ $[1,15]$. In general, temperatures lower than this may be less optimal for lichen-forming algal or cyanobacterial photosynthesis and temperatures higher than this may damage the photosynthetic partner within the lichen, and presumably RNA transcription.

While the $1 \mathrm{~h}, 4 \mathrm{~h}$, and $24 \mathrm{~h}$ rehydration periods at $20^{\circ} \mathrm{C}$ in the light provided the highest concentration of RNA, and $4 \mathrm{~h}$ provided the highest quality of RNA, the quantity and quality fluctuated within the first $4 \mathrm{~h}$ of testing. These fluctuations may reflect a combination of time needed to revive the thallus, plus another period for acclimation to ambient conditions. Photosynthesis and metabolism have been reported to begin within minutes after rehydration in the lichen, Ramalina lacera [27], but acclimation to ambient conditions may take longer periods of time, e.g. to fully activate enzymes. Ferrar and Smith [28] and [1] showed that revival of a lichen and a moss occurred within $2 \mathrm{~h}$ of rehydration. Here, $4 \mathrm{~h}$ appear to provide an adequate period for the thallus to reach a steady state, as there was either no increase, or a reduction, in the quantity and quality of RNA and cDNA at $24 \mathrm{~h}$. Limitation of the amount of light to $1 \mathrm{~h}$ instead of $4 \mathrm{~h}$ may be beneficial since high light has been shown to cause the thallus temperature to increase and damage the thallus even when dry [6]. The higher concentration of RNA in light may be explained if genes for light activated photosynthetic enzymes were transcribed, producing a larger amount of RNA immediately upon rehydration, as has been observed in $R$. lacera [27] and in a poikilohydric moss [1].

\section{Conclusion}

A steady-state condition that may be representative of the natural lichen is attained by L. pulmonaria thalli $4 \mathrm{~h}$ after rehydration, as determined by direct assessment of total RNA as well as by examination of cDNA quality. Such knowledge simplifies sample collection and in situ processing, allowing much greater flexibility for storage and transport of specimens without use of specialized reagents to assure RNA integrity. Experimentation to further our understanding of this model organism and other poikilohydric lichens may be 

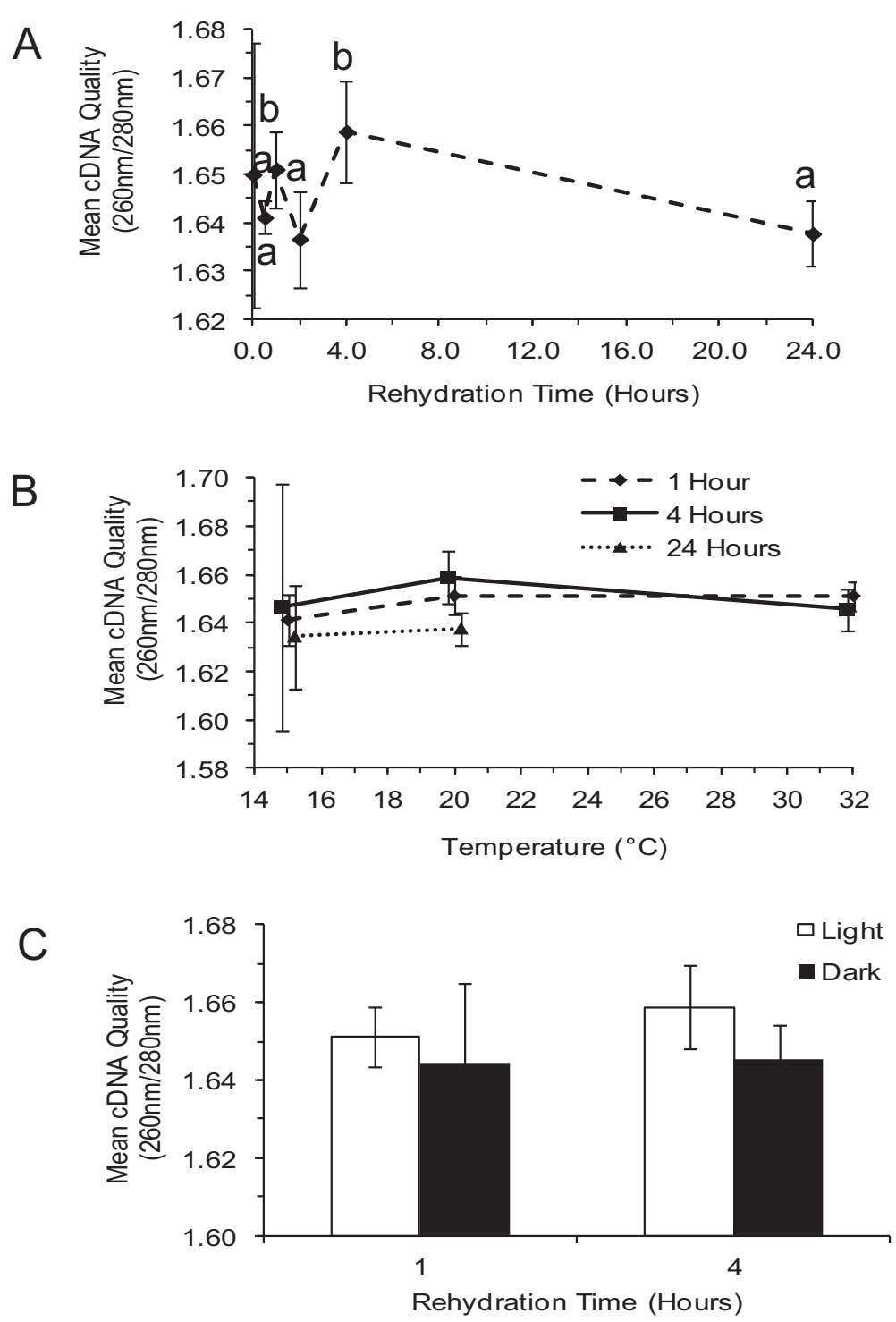

Figure 4 The effect of rehydration conditions on cDNA quality $\left(\mathbf{A}_{\mathbf{2 6 0 / 2 8 0}}\right)$. A. Effect of rehydration time (hours) at $20^{\circ} \mathrm{C}$ in the light. $\mathbf{B}$. Effect of temperature for rehydration times of $1 \mathrm{~h}, 4 \mathrm{~h}$, and $24 \mathrm{~h}$ in the light. $\mathbf{C}$. Effect of light for rehydration times of $1 \mathrm{~h}$ and $4 \mathrm{~h}$ at $20^{\circ} \mathrm{C}$. Error bars represent standard deviations of three replicates. Different lowercase letters indicate significantly different results; figures without lowercase letters show results that are not significantly different.

pursued with some confidence that steady state conditions can be reached.

\section{Abbreviations}

cDNA: Complementary DNA; DW: Dry weight; nifH: Nitrogenase gene; mtr SSU: Mitochondrial small subunit gene; Lpu_27: A simple sequence repeat

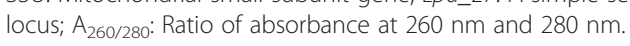

\section{Competing interests}

The authors declare they have no competing interests.

\section{Authors' contributions}

JD contributed to study design, carried out all lab work and drafted the manuscript. VM collected the specimens, provided critical advice on the analysis and interpretation of data, and made significant revisions to the manuscript. MN provided funding, designed the study, provided advice and training to JD on the molecular biology, and made critical revisions of the manuscript. All authors have given final approval of the manuscript.

\section{Acknowledgements}

The authors thank P. Loewen, Department of Microbiology, University of Manitoba for providing Pfu DNA polymerase. Funding was provided by a Natural Sciences and Engineering Research Council of Canada Discovery Grant to MPN and a University of Manitoba student award to JD.

\section{Author details}

'Department of Biological Sciences, University of Manitoba, 50 Sifton Road, Winnipeg, MB R3T 2 N2, Canada. ${ }^{2}$ Department of Microbiology and Immunology, University of British Columbia, 2350 Health Sciences Mall, Vancouver, BC V6T 1Z3, Canada.

Received: 11 December 2013 Accepted: 8 July 2014

Published: 10 July 2014 


\section{References}

1. Oliver MJ, Dowd SE, Zaragoza J, Mauget SA, Payton PR: The rehydration transcriptome of the desiccation-tolerant bryophyte Tortula ruralis: transcript classification and analysis. BMC Genomics 2004, 5:89.

2. Nash TH (Ed): Lichen biology. Cambridge: Cambridge University Press; 1996.

3. Brodo IM, Sharnoff SD, Sharnoff S: Lichens of North America. New Haven, Conn: Yale University Press; 2001.

4. Jüriado I, Liira J, Csencsics D, Widmer I, Adolf C, Kohv K, Scheidegger C: Dispersal ecology of the endangered woodland lichen Lobaria pulmonaria in managed hemiboreal forest landscape. Biodivers Conserv 2011, 20:1803-1819.

5. Tschermak-Woess E: The algal partner. In CRC handbook of lichenology Volume 1. Edited by Galun M. Boca Raton, Florida, USA: CRC Press; 1988:39-92.

6. Gauslaa Y, Solhaug KA: High-light damage in air-dry thalli of the old forest lichen Lobaria pulmonaria - interactions of irradiance, exposure duration and high temperature. J Exp Bot 1999, 50:697-705.

7. Asplund J, Solhaug KA, Gauslaa Y: Fungal depsidones - an inducible or constitutive defence against herbivores in the lichen Lobaria pulmonaria? Basic Appl Ecol 2009, 10:273-278.

8. Fernández-Marín B, Becerril JM, Garcia-Plazaola Jl: Unravelling the roles of desiccation-induced xanthophyll cycle activity in darkness: a case study in Lobaria pulmonaria. Planta 2010, 231:1335-1342.

9. Werth S, Wagner HH, Holderegger R, Kalwij JM, Scheidegger C: Effect of disturbances on the genetic diversity of an old-forest associated lichen. Mol Ecol 2006, 15:911-921.

10. Singh G, Dal Grande F, Cornejo C, Schmitt I, Scheidegger C: Genetic basis of self-incompatibility in the lichen-forming fungus Lobaria pulmonaria and skewed frequency distribution of mating-type idiomorphs: Implications for conservation. PLOS ONE 2012, 7:e51402.

11. Walser JC, Gugerli F, Holderegger R, Kuonen D, Scheidegger C: Recombination and clonal propagation in different populations of the lichen Lobaria pulmonaria. Heredity 2004, 93:322-329.

12. Weissman L, Garty J, Hochman A: Rehydration of the lichen Ramalina lacera results in production of reactive oxygen species and nitric oxide and a decrease in antioxidants. Appl Environ Microbiol 2005, 71:2121-2129.

13. de los Rios A, Ramirez R, Estevez P: RNase in Lasallia hispanica and Cornicularia normoerica: multiplicity of electromorphs and activity changes during a hydration-dehydration cycle. J Exp Bot 1996, 47:1927-1933.

14. Imbeaud S, Graudens E, Boulanger V, Barlet X, Zaborski P, Eveno E, Mueller O, Schroeder A, Auffray C: Towards standardization of RNA quality assessment using user-independent classifiers of microcapillary electrophoresis traces. Nucl Acids Res 2005, 33:e56.

15. Junttila S, Lim K-J, Rudd S: Optimization and comparison of different methods for RNA isolation for CDNA library construction from the reindeer lichen Cladonia rangiferina. BMC Research Notes 2009, 2:204.

16. Miao VPW, Manoharan SS, Snaebjarnarson V, Andrésson OS: Expression of lec-1, a mycobiont gene encoding a galectin-like protein in the lichen Peltigera membranacea. Symbiosis 2012, 57:23-31.

17. Kampa A, Gagunashvili AN, Gulder TAM, Morinaka BI, Daolio C, Godejohann M, Miao VPW, Piel J, Andrésson OS: Metagenomic natural product discovery in lichen provides evidence for a family of biosynthetic pathways in diverse symbioses. P Natl Acad Sci USA 2013, 110:E3129-E3137. doi:10.1073/pnas.1305867110

18. Zoller S, Lutzoni F, Scheidegger C: Genetic variation within and among populations of the threatened lichen Lobaria pulmonaria in Switzerland and implications for its conservation. Mol Ecol 1999, 8:2049-2059.

19. Walser JC, Sperisen C, Soliva M, Scheidegger C: Fungus-specific microsatellite primers of lichens: application for the assessment of genetic variation on different spatial scales in Lobaria pulmonaria. Fungal Genet Biol 2003, 40:72-82.

20. Gaby JC, Buckley DH: A comprehensive evaluation of PCR primers to amplify the nifH gene of nitrogenase. PLOS ONE 2014, 9:E93883. doi:10.1371/journal.pone.0093883.

21. Widmer I, Dal Grande F, Cornejo C, Scheidegger C: Highly variable microsatellite markers for the fungal and algal symbionts of the lichen Lobaria pulmonaria and challenges in developing biont-specific molecular markers for fungal associations. Fungal Biology 2010, 114:538-544.

22. Grube M, DePriest PT, Gargas A, Hafellner J: DNA isolation from lichen ascomata. Mycol Res 1995, 99:1321-1324.

23. R: A language and environment for statistical computing. http:www.R-project.org/.
24. Honegger R: The impact of different long-term storage conditions on the viability of lichen-forming ascomycetes and their green algal photobiont, Trebouxia spp. Plant Biol 2003, 5:324-330.

25. Shirazi AM, Muir PS, McCune B: Environmental factors influencing the distribution of the lichens Lobaria oregana and L. pulmonaria. The Bryologist 1996, 99:12-18.

26. Liang W, Zhou Y, Wang L, You X, Zhang Y, Cheng C-L, Chen W: Ultrastructural, physiological and proteomic analysis of Nostoc flagelliforme in response to dehydration and rehydration. J Proteomics 2012, 75:5604-5627.

27. Weissman L, Garty J, Hochman A: Characterization of enzymatic antioxidants in the lichen Ramalina lacera and their response to rehydration. Appl Environ Microbiol 2005, 71:6508-6514.

28. Farrar JF, Smith DC: Ecological physiology of the lichen Hypogymnia physodes III. the importance of the rewetting phase. New Phytol 1976, 77:115-125.

doi:10.1186/1756-0500-7-442

Cite this article as: Doering et al:: Rehydration conditions for isolation of high quality RNA from the lichen Lobaria pulmonaria. BMC Research Notes 2014 7:442.

\section{Submit your next manuscript to BioMed Central and take full advantage of:}

- Convenient online submission

- Thorough peer review

- No space constraints or color figure charges

- Immediate publication on acceptance

- Inclusion in PubMed, CAS, Scopus and Google Scholar

- Research which is freely available for redistribution 